\title{
Water Quality Assessment For The Development Of Silvofishery Pattern Mangrove Crabs In Coastal Area, Polewali Mandar, West Sulawesi
}

\author{
Muhtar $^{1}$, Muhammad Yusri Karim², Mahatma Lanuru ${ }^{3}$ \\ 1) Department of Integrated Coastal Resource Management, Hasanuddin University, Indonesia \\ ${ }^{2)}$ Department of Fisheries, Hasanuddin University, Indonesia \\ ${ }^{3)}$ Department of Marine Science, Hasanuddin University, Indonesia \\ DOI: 10.29322/IJSRP.11.11.2021.p11952 \\ http://dx.doi.org/10.29322/IJSRP.11.11.2021.p11952
}

\begin{abstract}
Silvofishery is a concept that was developed as a form of sustainable fisheries cultivation with low inputs. The basic principle of this cultivation is the plural or dual use of mangroves without losing their natural ecosystem function. Various marine biota can be cultivated using silvofishery patterns, one of which is the mangrove crab. This study examines the water quality for the development of silvofishery-style mud crab cultivation in Polewali Mandar Regency, West Sulawesi Province. The method used is a survey method to obtain water quality data. Sampling was carried out at four research stations, namely Campalagian, Wonomulyo, Mapilli, and Binuang, measuring directly in the field and analyzing water quality at the Fisheries Cultivation Laboratory Pangkep State Agricultural Polytechnic, South Sulawesi. The results showed that the water quality parameters of the coastal area of Polewali Mandar Regency were entirely suitable for silvofishery mud crab cultivation.
\end{abstract}

Index Terms- mangrove, mud crab, silvofishery water quality

\section{INTRODUCTION}

$\Lambda \mathrm{s}$ one of the coastal ecosystems, mangroves have high Aecosystem productivity with various flora and fauna on the coastline in tropical and subtropical regions. In addition, mangroves preserve and maintain aquatic ecosystems, which have great ecological importance and shoreline stabilization, prevention of coastal erosion, sediment retention, reduction of nutrient retention, storm protection, and function as biological filters (Awn et al., 2016; Wamnebo et al., 2018).

In various cultivation cases, one cultivation often causes ecosystem degradation, including in the mangrove ecosystem, namely intensive pond cultivation (Asriani et al., 2019; Karim et al., 2019). Therefore, we need a management system that is economically and environmentally (ecologically) so that mangroves can still be utilized without damaging their natural functions, one of which is wanamina or silvofishery is a system of aquaculture in mangrove areas. Thus, the basic principle of the cultivation system is the dual use of the existence of mangroves without losing their natural ecosystem functions to obtain fishery products, and mangrove vegetation can still play a role as biological, ecological, and socio-cultural functions.
One of the aquatic biotas with a high economic value that is good for cultivation with a silvofishery pattern is the mangrove crab (Scylla sp.). Mangrove crabs live in mangrove forest areas (David, 2009) and are one of the commercial commodities in Indonesia (Yusuf et al., 2016; Tahya et al., 2016; Karim et al., 2019). Mangrove crab has a domestic and international market because the meat is delicious and highly nutritious, which contains various essential nutrients such as minerals and -3 fatty acids. So far, most consumers' needs for mangrove crabs are still met from the fluctuating wild catches (Catacutan, 2002; Karim, 2013). On the other hand, along with the increasing consumer demand for mangrove crabs, it has implications for the needs for intensive cultivation. One model of mangrove crab cultivation that is suitable to be applied to mangrove areas without damaging the ecosystem is the silvofishery cultivation system, so silvofishery is considered an environmentally sound cultivation model.

The coastal area of Polewali Mandar Regency has a reasonably extensive mangrove area and is spread in various subdistricts, including Campalagian, Wonomulyo, Mapilli, and Binuang sub-districts. The site is potential for the development of silvofishery-style mud crab cultivation. Various parameters can be used to assess the feasibility of mud crab cultivation, one of which is water quality parameters. Therefore, to further examine the possibility of developing silvofishery-style mud crab cultivation in the coastal area of Polewali Mandar Regency, West Sulawesi, a study is needed on this matter.

This study aims to examine the development of the cultivation of mud crab (Scylla sp.) in the coastal area of Polewali Mandar Regency based on water quality parameters. It is hoped that the results of this study can be used as a source of information and input for the government of Polewali Mandar Regency regarding the silvofishery pattern of mud crab cultivation.

\section{RESEARCH METHOD}

This research was conducted in the mangrove area of the coastal area of Polewali Mandar Regency, West Sulawesi, precisely in four stations, namely: Gonda, Campalagian District, Mampie, Wonomulyo District, Tanjung Buku, Mapilli District, and Sappoang, Binuang District. This research was conducted from April to September 2021. The sampling locations are presented in Figure 1. 


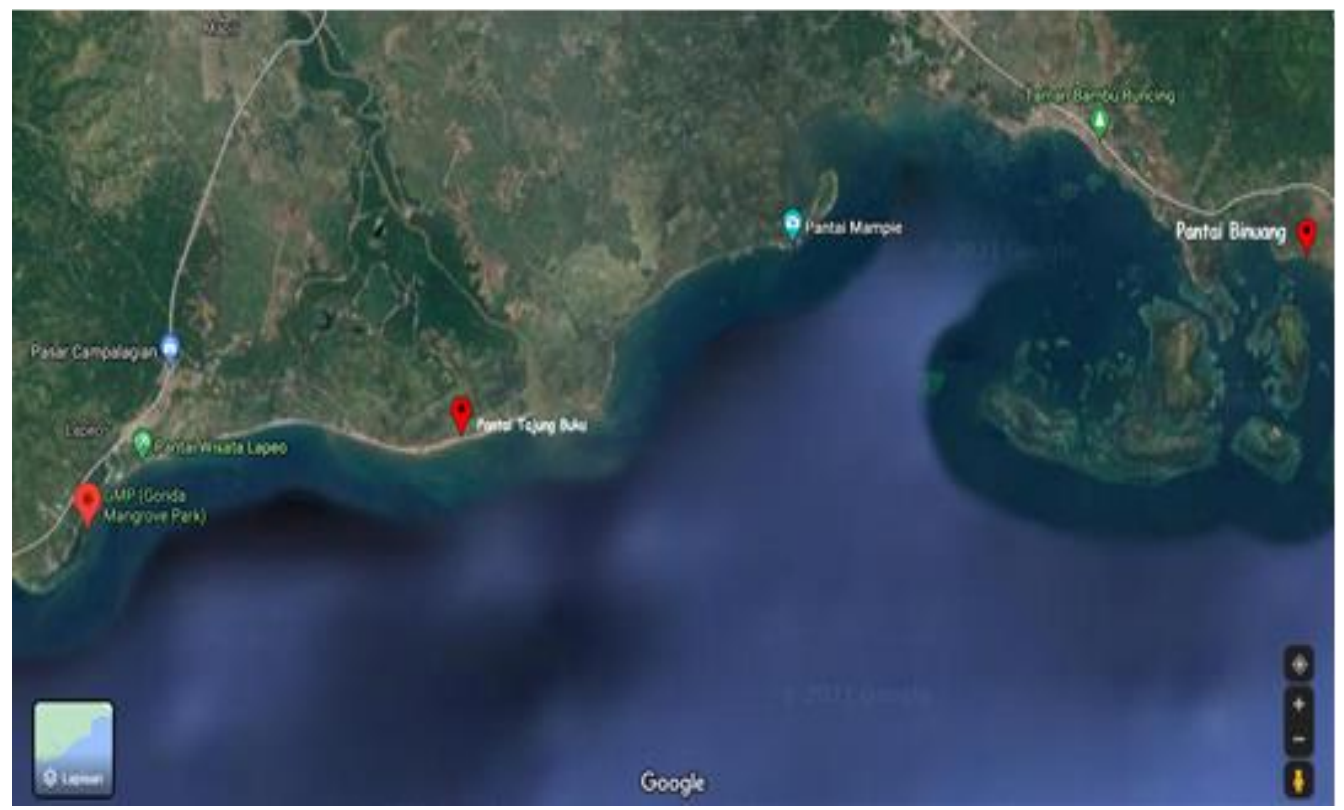

Figure 1. Sampling station

This study uses a survey method for sampling and data collection. Sampling was carried out at the research station. Water samples were taken four times with an interval of 10 days. Water samples were taken in the morning at 06.00, at noon, and in the afternoon at 17.00 using a sample bottle with a depth of $\pm 0.4-0.6$ $\mathrm{m}$ from the surface of the water depending on the water level at the time of sampling (Solihudin et al., 2011 in Winarsih et al., 2016).

The volume of sample water taken is $1,500 \mathrm{~mL}$ which is put into the sample bottle, and the sample bottle is put into the coolbox. Furthermore, the samples were analyzed in the laboratory according to the SNI procedure. Water quality parameters measured include physical parameters, namely: temperature, turbidity, and TSS, and chemical parameters include: salinity, $\mathrm{pH}$, dissolved oxygen, ammonia, and nitrite. Salinity, temperature, $\mathrm{pH}$, and dissolved oxygen were carried out directly, while ammonia, nitrite, turbidity, and TSS were analyzed in the laboratory. Salinity was measured using a hand refractometer, temperature with a mercury thermometer, $\mathrm{pH}$ with a $\mathrm{pH}$ meter, and dissolved oxygen (DO) with a DO meter. The turbidity was measured using a turbidity meter, while nitrite, turbidity, and TSS were measured using a spectrophotometer. The data obtained were analyzed descriptively based on the viability of the mud crab.

\section{RESULT AND DISCUSSION}

\section{Result}

Polewali Mandar Regency is one of the regencies included in the West Sulawesi Province, which has the potential to develop mud crab cultivation. Geographically, Polewali Mandar Regency is located at a position of $2^{\circ} 40^{\prime} 00^{\prime \prime}$ to $3^{\circ} 32^{\prime} 00^{\prime \prime}$ North Latitude and $118^{\circ} 40^{\prime} 27^{\prime \prime}$ to $119^{\circ} 32^{\prime} 27^{\prime \prime}$ East Longitude, with a land area of 2094 KM2 and a sea area of 460 KM2 with a coastline length of 94, 12 $\mathrm{km} 2$. Polewali Mandar Regency has the following administrative boundaries:

- In the north, it is bordered by Mamasa Regency and Majene Regency,

- To the south, it is bordered by the Makassar Strait Sea

- In the east, it is bordered by Mamasa Regency and Pinrang Regency, South Sulawesi Province

- $\quad$ To the west, it is bordered by Majene Regency

The area of Polewali Mandar Regency with a topograph area of $40 \%$, hilly $40 \%$ is mountainous, and the other $20 \%$ is flat. The air temperature in Polewali Mandar Regency is generally in the range of $21-31^{\circ} \mathrm{C}$ with an average of $26.4 \mathrm{C}$. Wind conditions are at weak to moderate speeds, with rainfall reaching 1,942 $\mathrm{mm} . / 158$ rainy days.

Polewali Mandar Regency is administratively divided into 16 (sixteen) sub-districts, consisting of eight sub-districts on the coast, and eight other sub-districts in the mountains. The number of villages in Polewali Mandar Regency is 144, and 23 villages. The population of Polewali Mandar Regency in 2020 is 524,922 people.

The average value of the water physicochemical parameters obtained during the study at each station is presented in Tables 1 and 2 . 
Table 1. The average value of water physics parameters at the research site

\begin{tabular}{lllll}
\hline & \multicolumn{2}{l}{ Locations (District) } & & \\
Parameters & Campalagian & Wonomulyo & Mapilli & Binuang \\
\hline Water Physics & & & & \\
Temperature $\left({ }^{\circ} \mathrm{C}\right)$ & 32,0 & 32,7 & 31,7 & 32,7 \\
Turbidity $(\mathrm{NTU})$ & 3,3 & 3,1 & 3,9 & 4,2 \\
TSS $(\mathrm{ppm})$ & 0,071 & 0,112 & 0,064 & 0,074 \\
\hline
\end{tabular}

Source : Secondary data, 2021

Tabel 2. The average value of water physics parameters at the research site

\begin{tabular}{lllll}
\hline & \multicolumn{2}{l}{ Locations (District) } & & \\
Parameters & Campalagian & Wonomulyo & Mapilli & Binuang \\
\hline Salinity (ppt) & 29 & 27,7 & 31,0 & 29,7 \\
pH & 7,9 & 7,9 & 7,8 & 7,7 \\
DO (ppm) & 4,4 & 4,4 & 4,4 & 4,1 \\
Ammonia (ppm) & 0,013 & 0,012 & 0,025 & 0,018 \\
Nitrite (ppm) & 0,002 & 0,001 & 0,001 & 0,002 \\
\hline
\end{tabular}

Source : Secondary data, 2021

Based on Table 1 above, it is known that the values of the physical parameters of water at the research site are temperatures ranging from 31.7-32.7oC, turbidity 3.1-4.2 NTU, and TSS 0.064$0.112 \mathrm{ppm}$. The values of the water chemical parameter range include: salinity ranging from 27.7-31.0 ppt, $\mathrm{pH}$ 7.7-7.9, DO 4.4$4.1 \mathrm{ppm}$, ammonia $0.12-0.25 \mathrm{ppm}$, and nitrate ranged from 0.001 to $0.002 \mathrm{ppm}$.

\section{Discussion}

Water temperature is an important parameter for the growth of cultured organisms. The results of surface water temperature measurements at the research location ranged from $31.7-32.7^{\circ} \mathrm{C}$. Temperature measurements were carried out in the morning, afternoon, and evening at each sub-station. The lowest temperature is $31.7^{\circ} \mathrm{C}$, and the highest is $32.7^{\circ} \mathrm{C}$. The water temperature of the research location is not significantly different, and this is probably due to the location of the mangrove vegetation, which is entirely in direct contact with the sea, except in Tanjung Buku, Mapillli District, which is located slightly deeper and surrounded by cultivated water areas but still affected by tidal movements of seawater. According to Karim (2013), a suitable temperature for mud crab cultivation ranges from 26-32 ${ }^{\circ} \mathrm{C}$. However, according to Tahmid et al. (2015), the temperature range of $25-35^{\circ} \mathrm{C}$ is still suitable habitat for adult crabs. Thus, the water temperature conditions of the research location are ideal for the maintenance of silvofishery mud crabs because adult crabs are cultivated, so an excess temperature of $0.7^{\circ} \mathrm{C}$ from the suitability threshold is considered not to interfere with crab growth.

The level of water turbidity is one of the physical parameters that can describe water pollution. The level of turbidity can be caused by the bottom substrate of the water, which is dominated by muddy clay so that with a bit of stirring, it can quickly increase the turbidity. The turbidity of the water is also a reflection of the amount of phytoplankton present in the rearing media and the number of suspended solids that accumulate in the rearing media. The level of turbidity obtained at the study site ranged from 3.1 to $4.2 \mathrm{NTU}$. The highest level of turbidity was obtained in Binuang, namely $4.2 \mathrm{NTU}$, and the lowest in Wonomulyo, namely 3.1 NTU. The turbidity value obtained was still in the appropriate range for the Silvofishery system of mud crab cultivation. According to Boyd (2015) the range of turbidity that is still good in aquaculture activities should be between 2-30 NTU.

Total suspension solid (TSS) or total suspended solids are residues of all solids (sand, mud and clay) or particles suspended in water. They can be in the form of living (biotic) components such as phytoplankton, zooplankton, bacteria, fungi, or dead (abiotic) components such as detritus and inorganic particles. Suspended material has a negative impact on water quality because it reduces the penetration of the sun into water bodies, increasing water turbidity, which causes growth disorders for producer organisms (Winnarsih et al., 2016; Wisha and Ondara, 2017; Hansen et al., 2021). High suspended solids in water can inhibit the work of the osmoregulation system and the visibility of aquatic organisms. The total suspended solids (TSS) content obtained at the study site ranged from 0.071-0.112 ppm. The highest total suspended solids (TSS) was found in the research location in Wonomulyo District, namely $0.112 \mathrm{ppm}$. This value is included in the very good category. According to Ong and Ransangan (2018), TSS concentration for marine life is $<50 \mathrm{ppm}$.

Mangrove crabs are able to live in conditions of wide salinity, which is between 5-40 ppt (Setiawan and Triyatno, 2012), but for optimum life needs, mangrove crabs can be kept in a salinity range of 10-25 ppt (Shelley \& Lovatelli, 2011). Meanwhile, according to Karim (2013), good salinity for mud crab cultivation ranges from 15-30 ppt. The salinity at the study site has a salinity range between $27.7-31.0$ ppt. This range shows that in all the research areas, the salinity level is quite suitable for the growth of mud crab (Scylla sp). 
Aquatic organisms require water conditions with a certain degree of acidity $(\mathrm{pH})$. The $\mathrm{pH}$ value of water is influenced by the concentration of $\mathrm{CO}_{2}$, where during the day photosynthesis takes place, which causes the concentration of $\mathrm{CO}_{2}$ to decrease and the $\mathrm{pH}$ of the water to increase. On the other hand, at night, all organisms in the water release $\mathrm{CO}_{2}$ as a result of respiration so that the $\mathrm{pH}$ of the water decreases. However, brackish water is well buffered so that the $\mathrm{pH}$ of the water rarely drops below 6.5 or increases to a value of 9 , so that adverse effects on mud crabs are rare. The degree of acidity $(\mathrm{pH})$ obtained at the time of measurement at the study site ranged from 7.7 to 7.9 . In this case, there is no significant difference in the degree of water acidity $(\mathrm{pH})$ between the four research locations. This range is still within the tolerance value of mud crab. According to Karim (2013), Ganesh et al., (2015), and Syafaat et al., (2021), a good pH for mud crab cultivation ranges from 7.5 to 8.5. Thus, the water acidity $(\mathrm{pH})$ level at all research sites is suitable for the silvofishery system of mud crab culture.

Dissolved oxygen (DO) is the most critical water quality modifier for the life of aquatic organisms. The life of living things in water (plants and aquatic biota) depends on the ability of water to maintain the minimum required to DO concentration. The results of the measurement of dissolved oxygen (DO) at the study site ranged from 4.1 to $4.4 \mathrm{ppm}$. This value is above the minimum DO threshold. According to Susanto Pedopoli and Ramudu (2014), the need for oxygen for the life and growth of mud crabs is $>4.0 \mathrm{ppm}$. According to Boyd (2015) that in general, good oxygen levels for the cultivation of aquatic biota are $>3 \mathrm{ppm}$. Thus, DO levels in all study sites are suitable for mud crab maintenance because their values are above the minimum required threshold.

Ammonia is the main compound derived from nitrogenous waste in waters from aquatic organisms (Neil et al., 2005). Ammonia in water is usually present in two forms, namely ammonia (NH3) which is dominantly toxic at high $\mathrm{pH}$, and ammonium ion $\left(\mathrm{NH}_{4}\right)$, which is non-toxic and dominant at low $\mathrm{pH}$ (Cavalli et al., 2000). Ammonia is toxic, so that in high concentrations, it can poison organisms (Boyd, 2015). The content of Ammonia $\left(\mathrm{NH}_{3}\right)$ in the waters of the study site is in the range of 0.012-0.025 ppm. The value of this anomia range is suitable for the life of the mud crab. According to Sari et al. (2020), the seawater quality standard for $\mathrm{NH}_{3}$ is $0.3 \mathrm{ppm}$ for marine biota. According to Karim (2013; Ganesh et al., 2015), mud crabs can grow well, at concentrations of ammonia in the media not more than $0.1 \mathrm{ppm}$

Nitrite $\left(\mathrm{NO}_{2}\right)$ for aquatic organisms, including crabs directly, nitrite is a type of toxic material, usually formed in intensive cultivation or polluted waters (Ramdhani et al., 2013; Weihrauch et al., 2018; Rochmah and Mangkoedihardjo, 2019). Nitrite accumulation can worsen water quality, reduce growth, increase oxygen consumption and ammonia excretion, and increase mortality. The concentration of nitrite found at the study site ranged from 0.001 to $0.002 \mathrm{ppm}$. According to Boyd (2015) and Wasielesky et al., (2017), nitrite concentrations exceeding $0.05 \mathrm{mg} / \mathrm{L}$ can be toxic to marine biota. However, according to Karim (2013), so that mangrove crabs can grow well, nitrite levels are $<0.05 \mathrm{ppm}$. Thus, based on the nitrite concentration at the research site, the coastal area of Polewali Mandar Regency is suitable for silvofishery mud crab cultivation, with the lowest nitrite concentration at Station 2 Tanjung Buku and the highest at Station 1 Gonda.

\section{CONCLUSION}

Based on the study results, it can be concluded that the mangrove area of the coastal area of Polewali Mandar Regency is suitable for the development of silvofishery mud crab cultivation in terms of water quality aspects.

\section{REFERENCES}

[1] Awn M S M, Yulianda F, Yonvitne. 2016 Characteristics and above-Ground Biomass of Mangrove Species in Enggano Island, Bengkulu, Sumatra, Indonesia. International Journal of Advanced Engineering, Management and Science 2(7):1084-1091.

[2] Asriani, Karim M Y, Azis H Y. 2019. Study of Mud Crab (Scylla olivacea) Growth Which Cultivated In Silvofishery System In Various Types of Mangrove Vegetation. International Journal of Scientific and Research Publications, Vol. 9, Issue 2: 376-381.

[3] Boyd C E. 2015. Water Quality in Ponds for Aquaculture. Birmingham Publishing Co., Alabama.

[4] Catacutan MR. 2002. Growth and Body Composition of Juvenile Mud Crab, Scylla serrata, Fed Different Dietary Protein and Lipid Levels and Protein to Energy Ratio. Aquaculture 208: 113-123.

[5] Cavalli RO, Berghe EV, Lavens P, Thuy NTT, Wille M, Sorgeloos P. 2000. Ammonia Toxicity as A Criterion for The Evaluation of Larval Quality in The Prawn Macrobrachium rosenbergii. Comp. Biochem. Physiol. 125C: 333-343.

[6] David M H O. 2009. Mud Crab (Scylla serrata) Culture: Understanding the Technology in a Silvofisheries Perspective. Western Indian Ocean J. Mar. Sci., Vol. 8 (1): 127-137.

[7] Ganesh, K., YCTS. Raj, S. Perumal, P. Srinivasan, and A. Sethuramalingam, A. Breeding, larval rearing and farming of mangrove crab, Scylla serrata (Forskal, 1775). In Advances in Marine and Brackishwater Aquaculture; Springer Science and Business Media LLC: Berlin, Germany, 2015; pp. $163-$ 172.

[8] Karim M Y. 2013. Mangrove Crab (Scylla sp.) (Bioecology, Cultivation and Hatchery). Yarsif Watampone, Jakarta.

[9] Karim M Y, Azis H Y, Amri K, Nurfadilah, Alimuddin, Muslimin, Anton. 2019. Fattening of Mangrove Crab (Scylla olivacea) By Silvofishery System with Different Feeding Frequency. International Journal of Scientific and Research Publications, Vol. 9, Issue 3: 53-57.

[10] Neil LL, Fotedar R, Shelley CC. 2005. Effects of Acute and Chronic Toxicity of Unionized Ammonia on Mud Crab, Scylla serrata (Forsskal, 1755) Larvae. Aqua. Res., 36: 927-932.

[11] Ong F S, Ransangan J. 2018. Assessment of Spatial and Temporal Variations of Water Quality for Future Mariculture Operation in Ambong Bay, Sabah, Malaysia. Open Journal of Marine Science, 8 1-19.

[12] Pedapoli S., Ramudu K. R., 2014 Effect of Water Quality Parameters on Growth and Survivability of Mud Crab (Scylla Tranquebarica) In Growth Out Culture At Kakinada Coast, Andhra Pradesh. International Journal of Fisheries And Aquatic Studies, 2(2):163-166.

[13] Ramdhani N, Kumari S, Bux F. 2013. Distribution of Nitrosomonas-Related AmmoniaOxidizing Bacteria and Nitrobacter-Related Nitrite-Oxidizing Bacteria in Two Full-Scale Biological Nutrient Removal Plants. Water Environment Research, Vol. 85, Number 4: 374-381.

[14] Rochmah W N, Mangkoedihardjo S. 2019. Toxicity Effects of Organic Substances on Nitrification Efficiency. IOP Conf. Series: Earth and Environmental Science, 506 (2020) 012011: 1-7.

[15] Sari A, Tuwo A, Rani C, Saru A. 2020. Water Quality Study and Pollution Index Based on Physicschemical Parameters in The Youtefa Bay Tourism Area, Jayapura. IOP Conf. Series: Earth And Environmental Science 564 (2020) 012030 Doi:10.1088/1755-1315/564/1/012030.

[16] Setiawan F, Triyanto. 2012. Land Fitness Study For Development Silvofishery Mangrove Crab (Scylla serrata) in Berau District, East Kalimantan. Limnotek, 19 (2) : 158-165. 
[17] Shelley C, Lovatelli A. 2011. Mud Crab Aquaculture A Practical Manual. FAO Fisheries and Aquaculture Technical Paper. Food And Agriculture Organization of The United Nations. Rome. Sharil, I, 2008.

[18] Syafaat M N, Azra M N, Waiho K, Fazhan H, Abol-Munafi A B, Ishak S D, Syahnon M, Ghazali A, Ma H, Ikhwanuddin M. 2021. Genus Scylla: A Review of the Nursery Culture of Mud Crabs, Current Progress and Future Directions. Animals, Vol. 11, 2034: 1-15.

[19] Tahmid M , Fahrudin A, Wardiatno Y. 2015. Habitat Quality Mud Crab (Scylla serrata) In Mangrove Ecosystem of Bintan Bay, Bintan Distric, Riau Islands. Journal of Tropical Marine Science And Technology, Vol. 7, No. 2: 535-551.

[20] Tahya A M, Zairin Jr M, Boediono A, Artika I M, Suprayudi M A. 2016 Expression of RNA Encode FAMeT in Mandibular Organ of Mud Crabs Scylla olivacea. International Journal of PharmTech Research, vol. 9 (3):219223.

[21] Yusuf S, Soejoedono R D, Mayasari N L P I, Tahya A M. 2016 RNA Expression of Farnesoic Acid O-Methyl Transferase in Mandibular Organ of Intermolt and Premolt Mud Crabs Scylla olivacea. AACL Bioflux, Vol. 9(2):270-275.

[22] Wamnebo M I, Karim M Y, Syamsuddin R, Yunus B. 2018. Biophysicochemical analysis of mangrove area of Kayeli Bay, Buru Regency, Maluku Province, Indonesia for the development of mud crab Scylla sp. culture with silvofishery system. AACL Bioflux, Vol. 11, Issue 4: 11301135.

[23] Wasielesky W J, Poersch L H, Martins T G, Miranda-Filho K C. 2017. Chronic Effects of Nitrogenous Compounds on Survival and Growth of Juvenile Pink Shrimp. Braz. J. Biol., Vol. 77 (3): 558-565.
[24] Weihrauch D, Josseph G, Allen G J P. 2018. Ammonia Excretion in Aquatic Invertebrates: New Insights and Questions. Journal of Experimental Biology, 221(2): jeb169219.

[25] Winnarsih, Emiyarti, Afu L O A. 2016. Distribution of total suspended solid surfaces In Kendari Bay. Sapa Laut, Vol. 1 (2) 54-59.

[26] Wisha U J, Ondara K. 2017. Total Suspended Solid (TSS) Distributed by Tidal Currents during Low to High Tide Phase in the Waters of Sayung, Demak: Its Relations to Water Quality Parameters. Journal of Marine and Aquatic Sciences 3(2): 154-162.

\section{AUTHORS}

First Author - Muhtar, Department of Integrated Coastal Resource Management, Hasanuddin University, Indonesia Second Author - Muhammad Yusri Karim, Department of Fisheries, Hasanuddin University, Indonesia

Third Author - Mahatma Lanuru, Department of Marine Science, Hasanuddin University, Indonesia

Correspondence Author - mappagalamuhtar@gmail.com 